\title{
Influence of Pinewood Nematode, Bursaphelenchus xylophilus, on the Growth of Endoparasitic Fungus Esteya vermicola
}

\author{
Chun Yan Wang, Chung Ha Lee, Mi Ra Lee, Beom Sik Yun, Lei Liu, Zhen Wang, Zhe Ming Fang,
} Dong Liang Zhang, Zheng Li and Chang Keun Sung*

\section{Department of Food Science and Technology, College of Agriculture and Biotechnology, Chungnam National University, Tagion 305-764, Korea}

Received October 20, 2009 /Accepted April 28, 2010

\begin{abstract}
The influence of nematodes on nematophagous fungi has seldom been investigated. In the present study, the influence of pinewood nematode on its endoparasitic fungus, Esteya vermicola, was investigated systemically. Although both nematodal metabolite and nematodal homogenate could stimulate and speed up the growth of E. vermicola, the impact of nematodal metabolite was slightly higher than that of nematodal homogenate. In addition, a method was developed to investigate the influence of volatiles, discharged by pinewood nematodes in their metabolic process, on the growth of $E$. vermicola. Reproductive results were given and confirmed that nematodal volatiles have no influence on the cell growth of $E$. vermicola. This study may provide information for the application of $E$. vermicola as biological control agent of pinewood nematode.
\end{abstract}

Key words : Pinewood nematode, Esteya vermicola, nematodal metabolite, nematodal homogenate, volatiles

\section{Introduction}

Many investigations on attraction of nematodes to fungi have been conducted $[1,2,4-6,8,9]$. It was demonstrated that attraction of nematodes to culture filtrates, boiled exudative substances and living mycelia of several nematophagous fungi. Certain exudative and volatile compounds, which were continuously produced by living fungal mycelia, were suggested to be responsible for the attraction. However, the attraction and influence of nematodes on nematophagous fungi were hardly investigated. The effects of volatile compounds from nematodes on trap formation by a nematode-trapping fungus had been investigated, and found that no trap was induced by the volatile compounds of nematode origin [11]. Later, the volatile compounds exuded from axenicaily grown free-living nematodes, Panagrellus redivivus, were determined with gas chromatographic and mass spectrometric techniques. The effects of these compounds on induction of trap formation in the nematode-trapping fungus Arthrobotrys oligospora also were tested. According to the report, $\mathrm{CO}_{2}$ inhibited trap formation at $5-10 \%(\mathrm{v} / \mathrm{v}) \mathrm{CO}_{2}$ in air, whereas ammonia stimulated trap formation in a certain concentration range. No effects of ace-

\footnotetext{
*Corresponding author

Tel : +82-42-821-6722, Fax : +82-42-822-2287

E-mail : kchsung@cnu.ac.kr
}

tic and propionic acids were noted for the concentrations tested [10].

As the most serious forest disease, pine wilting disease is caused by the pinewood nematode (PWN), Bursaphelenchus xylophilus, and has devastated huge areas of pine forests to induce irreparable damage in forest ecosystems and industry. In South Korea, pine wilt disease was first detected in Gumjung Mt., Busan city in 1988 [15]. It has been 20 years since the first disease was reported, and now the area of pine wilting disease occupied approximately 7, 800 ha over 65 cities [3]. Esteya vermicola is the first recorded endoparasitic fungus of PWN and exhibits high infection activity in vitro $[7,13,14]$. Based on its high potential as a biological control agent against PWN, E. vermicola has been patented in the United States [12]. By adding nematode suspension directly to the pure culture of fungus, the influence of PWN on E. vermicola was investigated [13]. According to the result, PWN could stimulate the growth of $E$. vermicola and induce the mass production of infective conidia. However, the method used in this research was too crude and imperfectness. Since the pine wilt disease is a complex relationship among pine tree, fungi, bacteria and nematode, studies of microbe-nematode interrelationships may have significant practical implication. Accordingly, the purpose of present study was to investigate the influence of PWN on the growth of $E$. vermicola. This study may provide more information and knowledge for the development of $E$. vermicola as biological 
control agent to combat the pine wilt disease.

\section{Materials and methods}

\section{Culture of $E$. vermicola}

Esteya vermicola CNU 120806 was obtained from the Agriculture Bioscience Biotech Centre, Chungnam National University, Korea. It was maintained on potato dextrose agar (PDA) slant at $4^{\circ} \mathrm{C}$ and cultured on PDA plate at $26^{\circ} \mathrm{C}$.

\section{Monoxenic culture of B. xylophilus}

According to the method described by Wang et al. [13], PWN was cultured and isolated. Briefly, Botrytis cinerea KACC 40573 was cultured on PDA plate at $26^{\circ} \mathrm{C}$, and then inoculated with PWN while the fungus grew fully. Subsequently, the plate was cultured until fungal mycelia had been completely consumed. The cultured nematodes were separated from culture medium using the Baerman funnel technique.

Preparation of the nematodal metabolite (NM) and nematode homogenate $(\mathrm{NH})$

The harvested PWN were washed five times with sterile water to remove any remnant mycelia, suffered from the surface disinfection with $0.1 \% \mathrm{NaOCl}$ solution (sodium hypochlorite) for $1 \mathrm{~min}$, rinsed three times again with sterilized distilled water, and then prepared as aqueous suspension with sterilized distilled water.

$1 \mathrm{ml}$ aqueous suspension of nematodes (including about 30,000 individuals) was stood for 3 days with occasionally shaking at room temperature under the axenic conditions. In this period, the metabolite produced by nematodes was released into the water. The supernatant was filtrated with a sterile cellulose acetate millipore filter $(0.2 \mu \mathrm{m})$, mixed well with $10 \mathrm{ml}$ autoclaved $2 \%$ water agar (WA) (about $40^{\circ} \mathrm{C}$ ) and poured into a $9 \mathrm{~cm}$ diam. sterile Petri dish. One day later, NM discs $(1 \mathrm{~cm}$ diam.) were cut with a sterilized cork from the plate for the subsequent experiments.

In the parallel experiment, $1 \mathrm{ml}$ aqueous suspension of nematodes (including about 30,000 individuals) was immediately homogenized on an ice bath for $4 \mathrm{~min}$, in $30 \mathrm{~s}$ bursts (20\% of the maximal power) with $30 \mathrm{~s}$ pauses, using an ultrasonic homogenizer (4710 series, Cole-Palmer Instrument Co., Chicago, Illinois, USA). The obtained suspension was centrifuged at $15,000 \mathrm{rpm}$ for $10 \mathrm{~min}$ at $4^{\circ} \mathrm{C}$. Subsequently, the supernatant was filtrated and prepared as $\mathrm{NH}$ discs by exactly following the same method mentioned above.

\section{Influence of $\mathrm{NM}$ and $\mathrm{NH}$ on E. vermicola}

This assay was carried out on the $2 \%$ WA plate in a 9 $\mathrm{cm}$ diam. Petri dish. On a fresh WA plate, one WA disc was placed $0.5 \mathrm{~cm}$ from the edge of plate, and then one NM or NH disc was placed opposite to the WA disc $6 \mathrm{~cm}$ apart, $0.5 \mathrm{~cm}$ from the edge of plate. A very small piece of mycelia was transferred from the margin of 7-day-old pure culture of $E$. vermicola to the centre of the WA plate. After incubation at $26^{\circ} \mathrm{C}$ for 7 days, a line was drawn, which passed through the centre of the plate and was at right angle to the line of two discs. The mycelia area of $E$. vermicola on each side of the line was measured by using Motic Images Plus 2.0 ML (Motic China Group Co., Ltd). PDA disc was used as positive control and treated by exactly following the same procedure. Moreover, two WA discs were placed on a same WA plate as negative control.

$\mathrm{NM}$ and $\mathrm{NH}$ were diffused from their agar discs into the WA plate to establish a concentration gradient. Provided that they have an influence on the growth of E. vermicola, the fungal hyphae should grow rapidly and partially towards the discs of NM and NH rather than the WA discs. Accordingly, there should be a significant difference betweent the hyphal areas of $E$. vermicola on the two sides of the line. Otherwise, no statistically significant difference could be observed.

\section{Influence of nematodal volatiles on $E$. vermicola}

Method was developed to investigate the influence of nematodal volatiles on $E$. vermicola. Briefly, $B$. cinerea KACC 40573 was cultured on PDA plate for 8 days at $26^{\circ} \mathrm{C}$, and then inoculated with $0.2 \mathrm{ml}$ aqueous suspension of PWN (including about 10,000 individuals) at the centre of plate. On a fresh WA plate, a very small piece of mycelia was transferred from the margin of 7-day-old pure culture of $E$. vermicola to the centre of plate. The two plates were made a hole, respectively, at the point $1 \mathrm{~cm}$ from the edge. Subsequently, they were connected together with a sterile plastic hollow tube $(7 \mathrm{~cm}$ in length, $0.5 \mathrm{~cm}$ in diam.), which was inserted into the holes and perpendicular to the surface of two plates. The plate inoculated with $E$. vermicola was placed above that of nematode, so that they were parallel to each other. They were sealed well with parafilm and cultured at $26^{\circ} \mathrm{C}$ for 7 days. As control, a B. cinerea plate without nematodes was connected with the $E$. vermicola plate by fol- 
lowing the same way mention above.

In this period, nematodes reproduced rapidly by feeding on the mycelia of $B$. cinerea. Through the connected hollow tube, volatiles produced by PWN in their metabolic process could be easily diffused to the above $E$. vermicola plate. However, it was impossible for nematodes to crawl into the $E$. vermicola plate because the tube was long, upright and dry. Provided that the growth of $E$. vermicola could be influenced by the volatiles released by nematodes, the fungal hyphae should grow rapidly and partially towards the opening of tube, so that the colony was asymmetric. Otherwise, the colony of $E$. vermicola should be regularly round in shape.

\section{Data analysis}

Each assay consisted of five replicates. The data were analyzed using SPSS 17.0 version for Windows.

\section{Results}

\section{Influence of $\mathrm{NM}$ and $\mathrm{NH}$ on E. vermicola}

The hyphae of $E$. vermicola were hyaline and sparse on WA plates (Fig. 1). On the negative control plate, two WA discs were placed opposite to each other. The colony of $E$. vermicola was normally round in shape and the areas of mycelia on the two sides of line were no significantly different ( $>0.05$ ) (Fig. 1A, Fig. 2). However, the colonies of E. vermicola were asymmetric both on the plate inoculated with NM disc and that inoculated with $\mathrm{NH}$ disc. Since the fungal hyphae grew rapidly and obviously towards $\mathrm{NM}$ and $\mathrm{NH}$ discs, the hyphal areas on the side of $\mathrm{NM}$ and $\mathrm{NH}$ disc were significantly bigger $(p<0.01)$ than those on the side of WA disc (Fig. 1C-D, Fig. 2). The same phenomenon was observed on the plate inoculated with PDA disc as positive control. The hyphal area of E. vermicola on the side of PDA disc was statistically significant bigger $(p<0.01)$ than that on the side of WA disc (Fig. 1D, Fig. 2). It was suggested that both NM and $\mathrm{NH}$ could stimulate and speed up the growth of $E$. vermicola.

In addition, the mycelia area on the side of PDA disc was significantly bigger $(\mathrm{p}<0.01)$ than those on the side of NM and $\mathrm{NH}$ disc, that did not show significant difference ( $p>0.05)$ to each other. The same result was found with regard to the total hyphal area of $E$. vermicola. It was the significantly highest $(p<0.01)$ on the plate inoculated with PDA disc $\left(8.49 \mathrm{~cm}^{2} \pm 0.47\right)$, followed by those inoculated with NM $\left(5.3 \mathrm{~cm}^{2} \pm 0.24\right)$ and $\mathrm{NH}\left(5.1 \mathrm{~cm}^{2} \pm 0.29\right)$, and the significantly

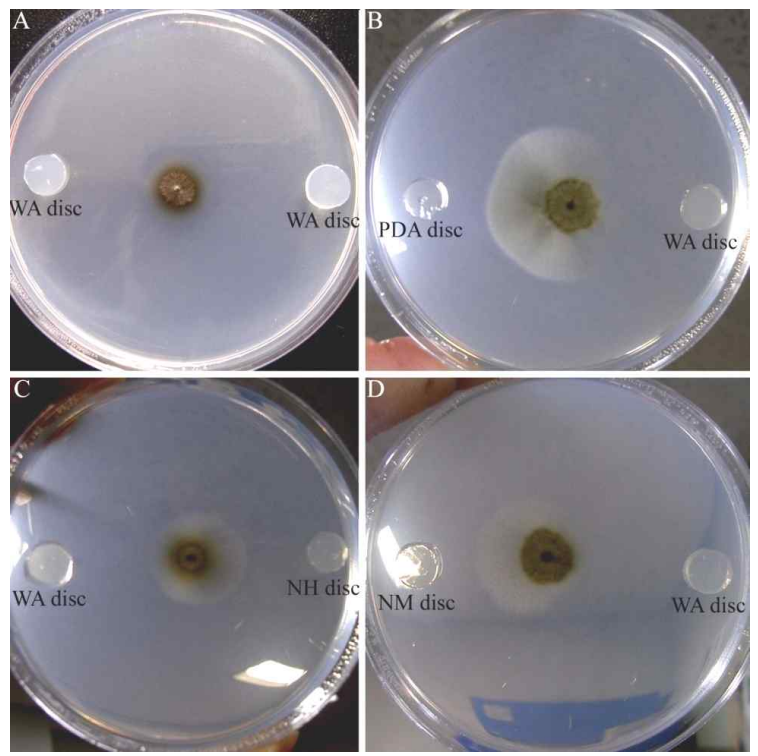

Fig. 1. Influence of $\mathrm{NH}$ (nematodal homogenate) and NM (nematodal metabolite) on the growth of $E$. vermicola. (A) Colony of $E$. vermicola on WA plate, which was inoculated with two WA discs on two opposite sides as negative control. (B) Colony of E. vermicola on WA plate, which was inoculated with one WA disc and one PDA disc on two opposite sides as positive control. (C) Colony of E. vermicola on WA plate, which was inoculated with one WA disc and one $\mathrm{NH}$ disc on two opposite sides. (D) Colony of E. vermicola on WA plate, which was inoculated with one WA disc and one NM disc on two opposite sides.

Fig. 2. Hyphal areas of E. vermicola on two sides of the symmetric line, which were inoculated with different agar discs. Each bar represents means \pm SE of 5 replicates. Bars with the different letter above are highly significantly different $(p<0.05)$. Bars with the same letter above are not significantly different $(p>0.05)$. 

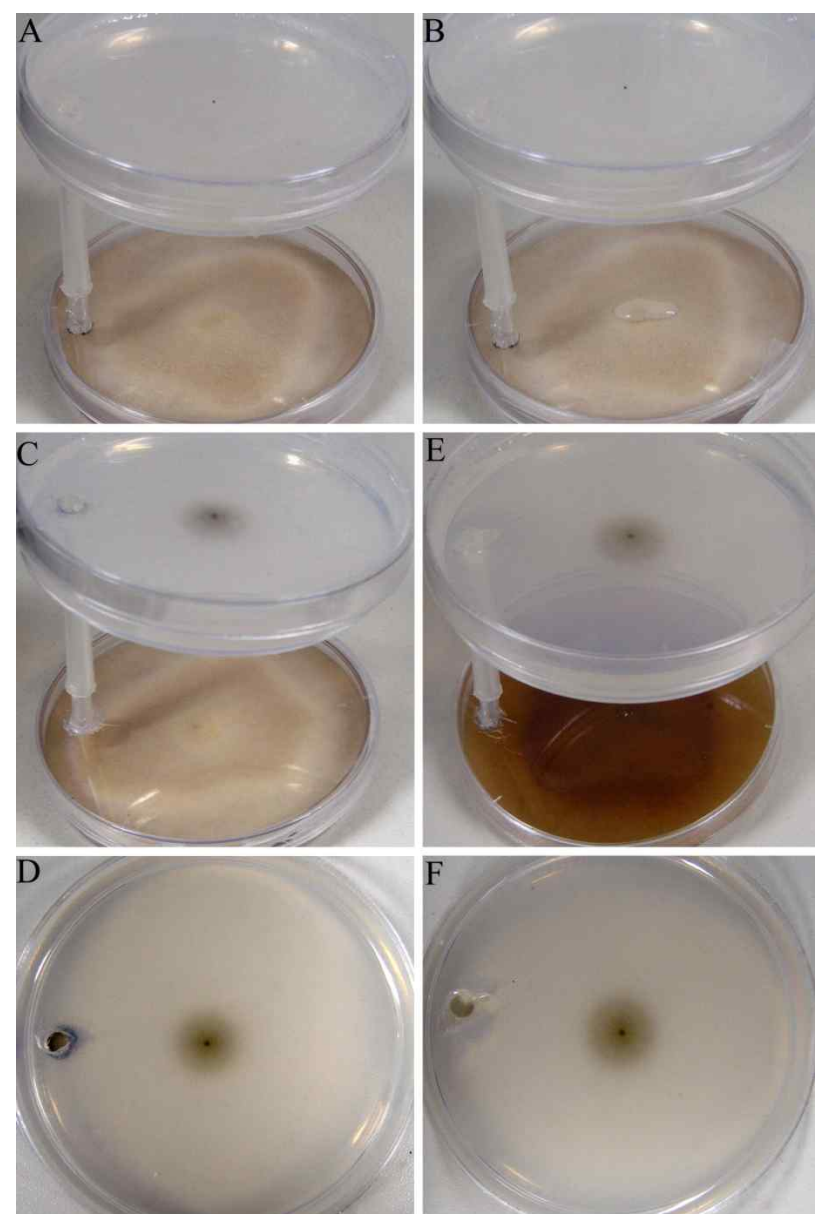

Fig. 3. Influence of nematodal volatiles on the growth of $E$. vermicola. (A) A WA plate inoculated with E. vermicola was connected with a $B$. cinerea plate without nematodes by a hollow tube, and used as control. (B) A plate inoculated with $E$. vermicola was connected with a $B$. cinerea plate inoculated with nematodes by a hollow tube. (C-D) The growth condition of E. vermicola on WA plate which was connected with a $B$. cinerea plate without nematodes. (E-F) The growth condition of $E$. vermicola on WA plate which was connected with a $B$. cinerea plate inoculated with nematodes.

lowest $(p<0.01)$ on the WA control plate $\left(2.2 \mathrm{~cm}^{2} \pm 0.02\right)$. Although the hyphal area on the NM plate was slightly bigger than that on the $\mathrm{NH}$ plate, there was no statistically significant difference $(p>0.05)$ between them. Therefore, the impacts of $\mathrm{NM}$ and $\mathrm{NH}$ on $E$. vermicola were relatively lower than that potato dextrose did in this study.

However, the proportion of mycelia area on the side of PDA disc from the total mycelia area $(70 \% \pm 1.37$, mean \pm SE, same below) was no significant difference $(p>0.05)$ with that on the side of NM disc $(69.2 \% \pm 1.19)$. They were significantly higher $(p<0.05)$ than that on the side of $\mathrm{NH}$ disc, which only reached $65.2 \%$. It seemed that the tropism of $E$. vermicola hyphae to potato dextrose and $\mathrm{NM}$ was higher than to $\mathrm{NH}$.

\section{Influence of nematodal volatiles on $E$. vermicola}

7 days after inoculation, the mycelia of $B$. cinerea have been completely consumed by PWN. At the same time, the amount of nematodes was increased sharply caused by their rapid multiplication. However, their movement was just limited to the plate they were introduced and no nematode was observed on the plate inoculated with $E$. vermicola. According to the result, the colony of $E$. vermicola was regularly round in shape, reached $1.5-1.8 \mathrm{~cm}$ in diam., and no obvious difference with control in both shape and size. It was suggested that the volatiles of PWN have no influence on the growth of $E$. vermicola in this study.

\section{Discussions}

In present study, the influence of PWN on the growth of $E$. vermicola was investigated systemically. Both $\mathrm{NM}$ and $\mathrm{NH}$ could stimulate and speed up the growth of E. vermicola, and the impact of NM was slightly higher than that of $\mathrm{NH}$. This result was consisted with the conclusion drawn from previous research [13]. Nevertheless, it is yet unclear about the exact ingredients of $\mathrm{NM}$ and $\mathrm{NH}$. Accordingly, it can not be explained why $\mathrm{NM}$ and $\mathrm{NH}$ can stimulate the growth of $E$. vermicola In the next step, the effective ingredients of them, which were responsible for the influence, should be analyzed by employing chemical method (HPLC, e.g.).

As the positive control, potato dextrose showed higher influence on the growth speed of $E$. vermicola than those NM and NH did in this study. The hyphal area on the plate inoculated with PDA disc was significantly bigger than those inoculated with NM and NH disc. The reason may be due to the abundant nutrition provided by potato dextrose, since $E$. vermicola showed rapider growth speed on the nutrition-richer culture medium [13]. It seemed that the hyphae of $E$. vermicola have a tropism to nutrition.

In addition, method was developed to investigate the influence of nematodal volatiles on the growth of E. vermicola, and gave reproductive results. According to the result, however, the nemarodal volatiles have no any influence on the growth of $E$. vermicola in this study.

\section{Acknowledgement}

This work was supported by the project from Ministry 
of Agriculture and Forestry, South Korea.

\section{References}

1. Balan, J., L. Krizkova, P. Nemec, and A. Kolozsvary. 1976. A qualitative method for detection of nematode attracting substances and proof of production of three different attractants by the fungus Monacrosporium rutgeriensis. Nematologica 22, 306-311.

2. Field, J. J. and J. Webster. 1977. Traps of predacious fungi attract nematodes. Trans. Brit. Mycol. Soc. 68, 467-469.

3. Han, H., Y. J. Chung, and S. C. Shin. 2008. First Report of Pine Wilt Disease on Pinus koraiensis in Korea. Plant Dis. 92, 1251.

4. Jasson, H. B. 1982. Attraction of nematodes to endoparasitic nematophagous fungi. Trans. Brit. Mycol. Soc. 79, 25-29.

5. Jasson, H. B. and B. Nordbring-Hertz. 1979. Attraction of nematodes to living mycelium of nematophagous fungi. $J$. Gen. Microbiol. 112, 89-93.

6. Jasson, H. B. and B. Nordbring-Hertz. 1980. Interactions between nematophagous fungi and plant-parasitic nematode: attraction, induction of trap formation and capture. Nematologica. 26, 383-389.

7. Liou, J. Y., J. Y. Shih, and S. S. Tzean. 1999. Esteya, a new nematophagous genus from Taiwan, attacking the pinewood nematode (Bursaphelenchus xylophilus). Mycol. Res. 103,
242-248.

8. Mamiya, Y. 2006. Attraction of the pinewood nematode to mycelium of some wood-decay fungi. Jpn. J. Nematol. 36, 1-9.

9. Monoson, H. L., A. G. Galsky, J. A. Griffin, and E. J. Mcgrath. 1973. Evidence for and partial characterization of a nematode attraction substance. Mycol. 65, 78-86.

10. Nordbring-Hertz, B. and G. Odham. 1980. Determination of volatile nematode exudates and their effects on a nematode-trapping fungus. Microb. Ecol. 6, 241-251.

11. Schenck, S. and D. Pramer. 1975. The effects of volatile compounds from nematodes on trap formation by a nematode-trapping fungus. Appl. Microbiol. 30, 496-497.

12. Tzean, S. S., J. Y. Liou, and J. Y. Shih. 2001. Nematophagous fungus Esteya vermicola, United States Patent 006168947B1.

13. Wang, C. Y., Z. M. Fang, B. S. Sun, L. J. Gu, K. Q. Zhang, and C. K. Sung. 2008. High infectivity of an endoparasitic fungus strain, Esteya vermicola, against nematodes. J. Microbiol. 46, 380-389.

14. Wang, C. Y., Z. M. Fang, Z. Wang, L. J. Gu, B. S. Sun, D. L. Zhang, and C. K. Sung. 2009. High infection activities of two Esteya vermicola isolates against pinewood nematode. Afr. J. Microbiol. Res. 3, 581-584.

15. Yi, C., B. Byun, J. Park, S. Yang, and K. Chang. 1989. First finding of the pine wood nematode, Bursaphelenchus xylophiIus (Steiner \& Buhrer) Nickle and its insect vector in Korea. Res. Rep. For. Res. Inst. Seoul 38, 141-149.

\section{초록 : Endoparasitic fungus Esteya vermic의 성장에 미치는 소나무 선충 Bursaphelenchus xylophilus의 영향 \\ 왕춘연 · 이청하 · 이미라 · 윤범식 · 유뢰 · 왕젠 · 방철명 · 장동량 · 이정 · 성창근 \\ (충남대학교 농업생명공학관 식품공학과)}

본 논문은 선충 포식성 곰팡이에 대한 선충의 영향을 조사한 연구로, 소나무 기생곰팡이인 E. vermicola에 미치 는 소나무 선충의 영향을 체계적으로 분석하였다. 선충 대사물과 선충 균질액 모두 E. vermicola의 성장을 빠르게 촉진하였으나, 선충 대사물이 선충 균질액보다 약간 높은 효과를 보였다. 또한 소나무 선충이 생성하는 휘발성 물질이 E. vermicola 성장에 미치는 영향을 분석하는 새로운 실험방법을 개발하였다. 본 연구결과에 따르면, 선충 의 휘발성 물질은 E. vermicola에 아무런 영향을 끼치지 않는다는 재현성 있는 결과를 도출하였다. 본 연구는 소나 무 선충의 생물학적인 조절인자로서 E. vermicda을 적용할 수 있는 정보를 제공할 수 있을 것이다. 